\title{
2014 Jack Kenney Award for Outstanding Service
}

\author{
Thomas J. Silhavy, Editor in Chief, Journal of Bacteriology
}

Department of Molecular Biology, Princeton University, Princeton, New Jersey, USA

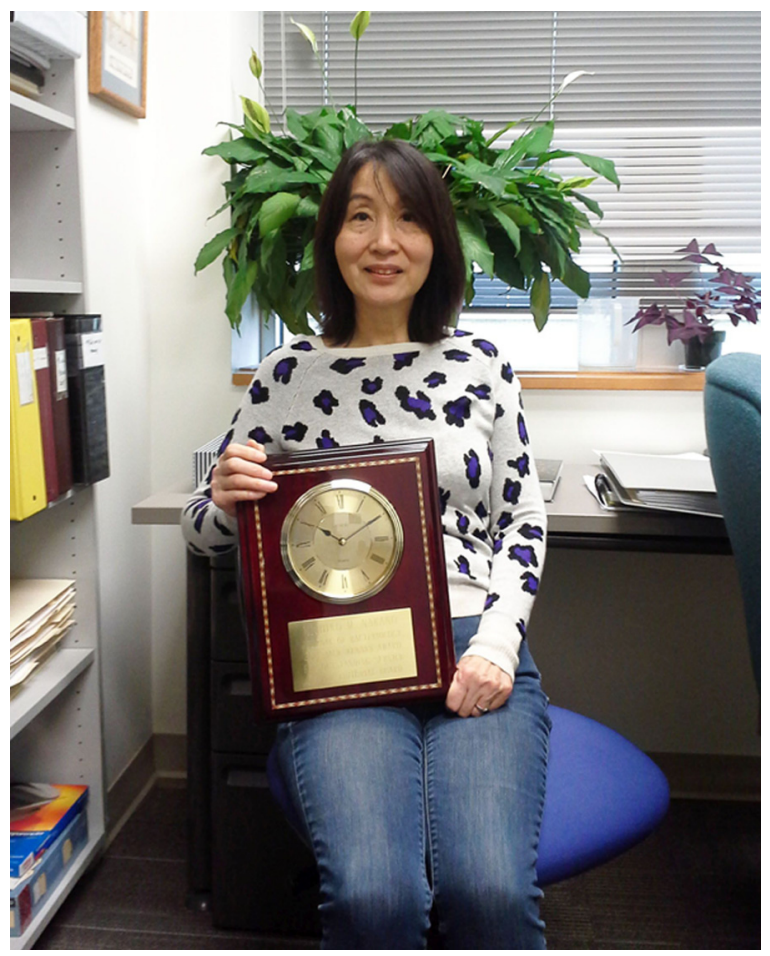

n April 30, 2010, Jack Kenney retired from the ASM Journals Department after 25 years of service. He served as the production editor for the Journal of Bacteriology for the last 13 of those years. I worked with Jack for almost 10 years. He was an especially gifted production editor; he solved countless problems for me when I was an editor and I know that he helped countless authors. Jack died suddenly and unexpectedly on July 10, 2010.

At the annual JB Editors' meeting following Jack's untimely death, it was unanimously decided to rename the JB Editors Award for Outstanding Service on the Editorial Board to the Jack Kenney Award for Outstanding Service.

At this year's Editors' meeting, Michiko Nakano was the editors' choice as the recipient of the Jack Kenney Award. Michiko is a research professor in the Division of Environmental and Biomolecular Systems at the Oregon Health and Science University. Her interests are in gene regulation in Bacillus species, especially regulatory mechanisms that respond to oxygen such as redox-sensitive stress responses and two-component signal transduction systems. Michiko won the award because no reviewer worked harder or performed better than she did last year. The editors know that she will readily accept assignments and return high-quality reviews in a timely manner. In the 12 months preceding this meeting, Michiko reviewed 13 manuscripts with an average turnaround time of 5 days. Moreover, never once during this period did she decline a review request. In appreciation of her efforts, Michiko was awarded the plaque she is shown holding.

The award this year is especially fitting because Michiko knew Jack Kenney and was one of the authors who benefited from his skill and experience. The editors of the Journal of Bacteriology are delighted to recognize and honor Michiko Nakano's service to our journal.

Citation Silhavy TJ. 2015. 2014 Jack Kenney Award for Outstanding Service. J Bacteriol 197:3. doi:10.1128/JB.02362-14.

Copyright @ 2015, American Society for Microbiology. All Rights Reserved. doi:10.1128/JB.02362-14 